\title{
Nyitás Kelet felé
}

\section{Opening Towards the East}

ÖSSZEFOGLALÁS

Az iszlám és a nyugati világ kapcsolata a 21. század gazdasági és politikai alapkérdése. A vallások közötti tolerancia, a kölcsönös elfogadás politikája lehet az egyetlen út, amely a békét a jövóben biztosítani tudja. A vallási szeparatizmus, intolerancia köntösében jelentkezô hatalmi góg minden formája megnehezítheti és megakadályozhatja a következó évszázadokban jelentkező globális problémák komplex megoldását.

Kulcsszavak: vallás, vallási tolerancia hiánya, konzervatív erô, emberi jogok, demokratikus szabadság

\section{SUMMARY}

Certain issues associated with religion are problematic. Scholars agree that religion can divide people. Lack of religious tolerance in multi-faith societies causes tension between communities practising different religions. Others believe that some religious values are too patriarchal and act as a conservative force, that they inhibit change, justifying an otherwise unjust social order, that they harm human rights and democratic freedom. Differences and disputes within denominations and religions may lead to conflicts, even to war. Religions may be used for political purposes, or may justify terrorism and violence.

Keywords: religion, lack of religious tolerance, conservative force, human rights, democratic freedom

\section{TÖRÖKORSZÁG VÁLASZÚTON}

„2001. szeptember 11. éles megvilágításban tárja elénk a dzsihád, illetve a keresztes háború idôszerúségét, akár iszlám, akár keresztény nézôpontból vizsgálódunk. A legfontosabb kérdés napjainkban az, hogy a két civilizáció képes lesze megvalósítani a békés egymás mellett élést, vagyis a civilizációk békéjét a 21 . században. A történelem azzal a tanulsággal

Dr. habil. Bertalan Péter, PhD, egyetemi docens, Kaposvári Egyetem, Kaposvár (drbertalanp@gmail.com). 


\section{Tudományos múhely}

szolgál, hogy a Nyugat és az iszlám közeledése csak akkor lehetséges, ha a vallást és a politikát szigorúan különválasztjuk egymástól. Az iszlám világ és Európa között mindig is az ész és a racionalitás jegyében került sor hídverésre, soha nem a vallás és a politika összefonódása révén, e kettố együttes megjelenése ugyanis mindig dzsihádba vagy keresztes háborúba torkollott" (Tibi, 2003, fülszöveg).

Magyarország helyzetét a nagy vonalakban megrajzolt, tág történelmi és geopolitikai dimenzióban nehéz meghatározni. Kis ország vagyunk, Nyugat- és Kelet-Európa találkozási vonalán, pontosabban Kelet-Közép-Európa szélén helyezkedünk el. Ebból adódóan hazánk a múltban, a többi szomszédos országgal együtt, a nagyhatalmak ütközési zónájába esett. Történelmünkben két hosszabb kataklizma jelentett kemény megpróbáltatásokkal teli idôszakot: a százötven éves török és a negyvenéves szovjet uralom. Ady találó metaforája: „kompország” hazánk változó geopolitikai helyzetét szemlélteti a történelmi folyamatban. Mai helyzetünk más: nem mi kopogtatunk Nyugat kapuján, inkább mi lettünk Keletés Délkelet-Európa kapuja, hiszen az Európai Unió tagjaként befogadó, közvetító feladat vár ránk a földrészünk különbözô részei között.

A 90-es években két szövetségi rendszeren alapuló állam omlott össze, a Szovjetunió és Jugoszlávia. Az elóbbi öszszeomlása nem volt pusztító erejú, mert a magállam centripetális, gravitációs ereje csillapította a hatást. Az utóbbiban múködött a puskaporos hordónak tekintett Balkán pusztító ereje. Bassam Tibi német professzor, akit az iszlamológia néven ismertté vált új szaktudomány megteremtôjének tekintenek, így jellemzi a kiala- kult helyzetet, elemzi a kiváltó okokat: „Az oszmán örökség a mai napig jól érzékelhetố, ennek egyik legmarkánsabb megnyilvánulása a kb. 8 millió balkáni muszlim és az ortodox (részben katolikus) keresztények között meghúzott vallási-etnikai határvonal. Balkán-szakértôk és az oszmán korszak kutatói egyetértenek abban, hogy az Oszmán Birodalom összeomlásának egyik kiváltó oka az európai nemzeteszme kialakulása és a világ nemzetállamokra való tagolódása volt. A Balkánon ez a jelenség jóval összetettebb. Tekintettel nyelvi és vallási törésvonalakra, e két lényegi meghatározóra, amelyekre a Balkánon a nemzeti identitás és nacionalizmus épült, a választóvonalak itt sokkal több veszélyt rejtenek magukban. A mai napig kézzelfogható oszmán örökség itt tehát komoly tehertételt jelent. A bosnyákok, a koszovói albánok és más balkáni muszlim népcsoportok, illetve az ortodox és katolikus keresztények között húzódó törésvonalak okozta súlyos gondokat a helyzetet jól ismeró szakértốk - túllépve a békülékeny hangot megütô, de lényegi újdonságot nem tartalmazó politikai prédikációkon - nem becsülik le. [...] Az oszmán örökségbốl fakadó etnikai és vallási természetú konfliktusok nem kezelhetốk NATO-bombázásokkal. Ezzel csak azt sikerült elérni, hogy a szerbek által végrehajtott szörnyú etnikai tisztogatást a koszovói albánok nem kevésbé gyalázatos, bosszúból elkövetett etnikai tisztogatása követte. Küszöbön áll a dzsihád és keresztes háborúk új korszaka" (Tibi, 2003:135).

Az idézet utolsó mondatának igazát megerôsíti, hogy 2007 után Európán végigsöpört a gazdasági és pénzügyi válság forgószele. Ennek hatására újból a figyelem középpontjába került a medi- 
terráneum, a Földközi-tenger medencéje. Portugáliától Görögországig erôteljes népmozgalom bontakozott $\mathrm{ki}$ a válság szociális következményeinek megszüntetéséért, veszélyeztetve a kormányokat és a közbiztonságot. A Földközi-tenger északi partvidékén jelentkezô válságsorozat viharosabb formákban tört ki a medence déli részén. Az arab tavasznak nevezett jelenség Tuniszból indult, és eljutott Szíriáig, ahol a dzsihádnak nevezett szent háború polgárháború jelleget öltött. Az arab társadalmak strukturális szempontból nagyon különbözôek. Néhány helyen diktátorok ültek és ülnek a népük nyakán, a társadalmat hálózati alapon szervezốdô családi klánok hatalma szövi át. Az iszlám szerepét is meg kell említeni, amely politikai jelenségként (Muszlim Testvériség mozgalom) vagy felekezeti szembenállásként (síita-szunnita) határozza meg a dzsihád jellegét. A Nyugat egyetlen esetben, Líbiában bombázott. A NATO beavatkozása csupán Kadhafi líbiai elnöktól szabadította meg az ellene lázadó erôket, de a törzsi ellentéteket nem simította el. Sok helyen még ma is dörögnek a fegyverek, és szedi ártatlan áldozatait a véres dzsihád.

A Közel-Keleten folyó harcok közül a legszívósabb a szíriai háború. Ennek tartósságát a szemben álló felek mögötti hatalmi eróegyensúly és érdek-összeütközés biztosítja. Oroszország és az USA, valamint Kína burkolt erôfelmérése ez, amelybe beleszól a nagyhatalmi státuszt az iszlám síita ágának dominanciájára törekvése révén a térségben elérni akaró Irán.

A szíriai háború a legnagyobb hatalmi erôvel rendelkezố iszlám állam, Törökország határai mentén zajlik. Törökország katonailag nem avatkozik az események- be, pedig erre több oka is lenne. A Szíriából a polgárháború elốl menekülốk nagy számban török területen keresnek menedéket. A polgárháborúban szemben álló erốk a síita-szunnita felekezeti ellentét alapján pusztítják egymást. Törökország a szunnita felekezet hazája, míg Asszad szíriai elnök mögött a síita többségú Irán áll. Törökország a NATO délkeleti szárnyának legerôsebb katonai hatalma. Törökországot a NATO és a Németországba emigrált jelentôs számú török vendégmunkás érdekeinek képviselete kapcsolja az Európai Unióhoz, amelynek kapuján a törökök már régóta kopogtatnak, de bebocsáttatást még nem nyertek.

Európa lett a keleti világ, elsôsorban az arab és a muzulmán afrikai népek kivándorlásának célpontja a magas életszínvonal, a szociális biztonság csalogató eredményeivel. A török kártya óvatos, taktikus használata, kijátszása nagyon fontos adu Németország és Merkel kancellár számára a továbbiakban is a hálózati alapú geopolitikai játszmában. Törökország nem tartozik az arab népek nagy családjába, elsôsorban az iszlám vallás köti össze ezzel a népcsaláddal. Európa számára ugyanakkor, a Közel-Kelet és Afrika államait is beleszámítva, a legmodernebb, az európai államokhoz hasonló berendezkedésú állam, amely összekötố híd lehet Európa és a muzulmán világ között. Ez válik a német kormány új keleti politikájának alapjává. Itt csatlakozik a magyar kormány keleti nyitás néven meghirdetett új külpolitikai stratégiája az EU elképzeléseihez.

Ahhoz, hogy jobban megértsük a magyar külpolitikai szándékok realitását, röviden vissza kell pillantanunk a múltba, amely nélkül a jelen nem igazán érthetố. A türk-török elnevezés a 6 . században bukkant fel. A türk névvel megjelölt nép- 
csoportok ôsei Közép-Ázsiában laktak, itt alakult meg 550 körül az elsố török államalakulat. Ez a birodalom mintegy 700 körül az Aral-tótól Mandzsúriáig terjedt. Harminc évvel késôbb kialakult az Orhon mentén az Ujgur Birodalom. 1300 körül a bizánci határ menti türk törzsek kerültek hatalomra. Ettốl kezdve az Oszmán Birodalom az évszázadok folyamán nôtt világbirodalommá. Történetének százötven éve kapcsolódik a magyar történelemhez. 1683-ban az oszmán-török seregek Bécs sikertelen ostroma miatt olyan kudarcot szenvedtek, amely elvezetett az Oszmán Birodalom zsugorodásához.

A modern Törökország története 1922-ben kezdôdött, amikor kimondták a szultanátus megszüntetését. A nemzetgyúlés 1923-ban kikiáltotta a köztársaságot. Elnökévé Musztafa Kemál pasát, miniszterelnökévé pedig Ismet pasát választotta. Az ország fốvárosa Isztambul helyett Ankara lett. Kemál a hatalomátvételkor meghirdette az állam és az egyház szétválasztását, valamint a belsố és a külsố békét. Elve szerint - etatizmus - az állam tevékenyen részt vesz a gazdasági életben, és gazdaságilag teljesen független a külföldtől. A kormány földreformot hirdetett (amely nem valósult meg), és államosította a kulcsiparágakat és a közlekedést. Az állam és az egyház szétválasztásával megtörték a feudális-klerikális hatalomgyakorlást. Az egyházi bíróságokat és iskolákat bezárták. Az 1928-as alkotmánymódosítás értelmében az iszlám többé nem volt államvallás. Megszüntették a fez viselését, az asszonyoknak nem kellett többé arcfátylat hordaniuk. Törökország modernizálódása azonban ezzel nem zárult le (Balázs, 2009:378). A mai Törökország megszületéséig még hosszú út vezetett (Világtörténelmi enciklopédia, 2008).
Kemál Atatürk lebontott egy muzulmán teokratikus államot, és helyén egy modern polgári köztársaságot állított fel. Politikája, államépítố tevékenysége a mának is szól. Az iszlám világ számos állama ma is teokratikus jellegú. A modernizálódás globalisztikus folyamatával szemben a polgári jellegú világi államot fenyegeti a visszarendezôdés veszélye. A pániszlám törekvések vissza akarják állítani a fundamentalista, teokratikus államot. Ennek négy alapvetố oka van: 1 . A modernizmus erôszakos túlkapásai által kiváltott ellenállás; 2. A gazdasági átalakulás torzulásai elmélyítették a szociális ellentéteket; 3 . Az ötvenes évektôl kezdve a hagyományokhoz ragaszkodó konzervatív felfogás, szokásrend lejáratása; 4 . A nyugati hatalmak politikája (elsôsorban az USA) démonizálja az iszlám vezetôket, és a letûnôfélben levô gyarmatosítás módszereivel eladósítja, nincstelenekké teszi a muzulmán államokat (Sardar-Malik, 2005:158).

Az Iszlám Állam az iszlám törvény, a saría normáinak visszaállítására törekszik, a politikai hatalmat részben vagy teljes egészében a hittudósok és az iszlamista mozgalmak vezetôi gyakorolják. A saría bevezetése a nốk jogaival, büntetôjoggal kapcsolatos bírói döntés. Nagy nyilvánosságot kapnak az iszlám büntetések, például a korbácsolás vagy a csonkítás. Az így született alakzat egy szigorú, elmaradott és szélsốséges törvények szerint múköőó állam, amely az iszlám és a Korán tanításaival ellenkezó értékeket képvisel, és annak nevében követi el túlkapásait. Az önjelölt iszlám államok nem tekinthetôk többnek az uralkodó réteg, család vagy hadsereg cinikus önigazolásánál (SardarMalik, 2005:159).

Törökországot is elérte az arab tavasz néven indult, erôteljes politikai mozga- 
lom. A kormány, élén Erdogan miniszterelnökkel, nehéz helyzetbe került. Erdogant hosszú ideig tartó börtönbüntetése népszerúvé tette, ez játszott szerepet abban, hogy a politika élvonalába került. 2001. augusztus 14-én alakította újjá pártját, az Igazság és Fejlődés Pártot (török rövidítése AKP). „A párt annak a középosztálynak a szavazataira számít, amelynek társadalmi felemelkedését és az urbanizált területek felé áramlását az iszlamista diskurzus kísérte, s amelynek átgondolatlan modernségképében az iszlám identitás és az Európai Unióhoz való csatlakozás harmonikusan megférnek egymással. A párt programja - amely elutasítja az iszlamista címkét, és nem hivatkozik a vallásra - a gazdasági liberalizmust és az állam és társadalom kiegyezését hangsúlyozza, több demokráciát követel, s a laicitást, az Emberi jogok nyilatkozatát és az Emberi jogok európai egyezményét tekinti eszmei alapjainak. [...] A választási gyôzzelmet követó hetekben Erdogan körutat tett az európai fôvárosokban, hogy támogatást szerezzen Törökország EU-csatlakozásának. [...] Manapság az AKP-t támogató társadalmi rétegek szociális mobilitását az Európához való közeledés segíti eló, s a kontinens gazdasági virágzásában való részvétel vágya egyesíti egymással a világi és vallásos középosztályt" (Kepel, 2007:597-600).

Erdogan diplomáciája a pániszlamizmus okozta félelmek miatt gyakran nem eredményes. Törökország óvatos, kis lépésekkel próbált és próbál közeledni Európához, a Nyugathoz. Bekapcsolódott a nemzetközi szervezetekbe. Az IMF, a NATO tagja lett, és tagja az OECD-nek, valamint az Európai Biztonsági és Együttmúködési Értekezletnek.

A nagy összefüggések miatt érdemes megemlíteni, hogy az Oszmán Birodalom a 19. században fenyegette a harcos vahhábita államot. A vahhábita szekta a sivatagi és pusztai arab törzseket egyesítette a szent háborúban (Világtörténelmi enciklopédia, 2008:931). A gyengüló Oszmán Birodalom széthullásában érdekeltek voltak az európai gyarmatosító hatalmak, Anglia és Franciaország. A mediterráneum a 19. század elején a Szuezi-csatorna miatt vált a világ geostratégiai központjává. Nagy-Britannia ügyes politikával az egymás ellen harcoló arab törzseket, iszlám monarchiákat felhasználta az Oszmán Birodalom elleni harcokban. Elhintette a pánarab szellemiség, összefogás magjait a pániszlamizmus már hosszabb ideje ható vallásos ideológiája mellé (a kettó ötvözốdése nagyon veszélyes). Törökország Európa beteg embere lett, egyedül maradt, 1914 novemberében belépett a második világháborúba Németország oldalán. Az Oszmán Birodalom megsemmisült.

A Közel-Keleten ma két muzulmán állam emelkedik ki az iszlám országok közül: Törökország erôs hadseregével, a modernizáció iránti elkötelezettségével, és Irán, az atombomba megszerzésére törekvô középhatalom. A pániszlám törekvések alapvetố támogatója, a dzsiháddal, terrorral fenyegetôzô ország fel akarja borítani a kényes hatalmi egyensúlyt, gazdasági fegyvere a föld egyik leghatalmasabb olajkészlete.

Úgy tûnik, hogy többetnikumú Törökország jelentôs mérvú modernizációja ellenére is sok nehézséggel néz szembe a világpolitikában. Az iszlám fundamentalizmus a megindult fejlôdést veszélyezteti. Törökország a vele szemben félig-meddig bizalmatlan Európai Unió országai között kell hogy megtalálja a partnereket. Ebben a törekvésében Németország mellett a rokon népnek tekintett Magyaror- 
szág is támogatja a keleti nyitás politikája jegyében. Hazánk számára az Erdogankormánnyal megkötött sokoldalú, elsôsorban gazdasági jelentôségú egyezmény fontos. Bizakodva tekintve a jövóbe, várva Törökországban a politikai konszolidálódást, hazánk készséges, segítô útitársa lehet az EU-ba vezetố úton. Egyszer már Horvátország uniós tagságának ügyes diplomáciával való eredményes támogatásával sikerült elérnünk, hogy partnert szerezzünk magunknak. Törökországgal való diplomáciai együttmúködésünk nagy sikere lehet az európai külpolitikának is, amennyiben Törökország EU-ba való felvételének következményeként az iszlám és a kereszténység közötti civilizációs és vallási ellentétek csillapodnának.

\section{FELHASZnÁlt IRODAlOM}

Arany Anett - N. Rózsa Erzsébet - Szalai Máté (2016): Az Iszlám Állam Kalifátusa. Az átalakuló Közel-Kelet. Osiris Kiadó - Külügyi és Külgazdasági Intézet, Budapest.

Balázs Judit (2009): Törökország Kelet és Nyugat között. Nyugat-magyarországi Egyetemi Kiadó, Budapest-Kairó.

Kepel, Gilles (2007): Dzsihád. Európa Könyvkiadó, Budapest.

N. Rózsa Erzsébet (2015) : Az arab tavasz. A Közel-Kelet átalakulása. Osiris Kiadó - Külügyi és Külgazdasági Intézet, Budapest.

Sardar, Ziauddin - Malik, Zafar Abbas (2005): Iszlám másképp. Edge 2000 Kiadó, Budapest.

Tibi, Bassam (2003): Keresztes háború és dzsihád. Az iszlám és keresztény világ. Corvina Kiadó, Budapest.

Világtörténelmi enciklopédia (2008). 2. kötet, Kossuth Kiadó Zrt., Budapest, 1013-1022. 